\title{
PEMAHAMAN DAN PERSEPSI JENJANG KARIR MENINGKATKAN EFIKASI DIRI PERAWAT DALAM PEMBERIAN ASUHAN KEPERAWATAN
}

\author{
Amiruddin $^{1}$, Rr. Tutik Sri Hariyati ${ }^{2}$, Tuti Nuraini ${ }^{3}$ \\ 1. Prodi Keperawatan Belitung, Poltekkes Kemenkes Pangkalpinang \\ 2. Departemen Keperawatan Dasar, Fakultas Ilmu Keperawatan Universitas Indonesia. \\ 3. Departemen Keperawatan Dasar, Fakultas Ilmu Keperawatan Universitas Indonesia. \\ *Email Korespondensi: amir_alsyifa@yahoo.com
}

\begin{abstract}
Abstrak
Penerapan jenjang karir memiliki dampak meningkatkan kompetensi perawat, yang dipengaruhi oleh efikasi dirinya. Penelitian ini bertujuan mengetahui hubungan pemahaman dan persepsi jenjang karir dengan efikasi diri dalam pemberian asuhan keperawatan. Desain penelitian cross sectional eksplorative, besar sampel 182 perawat diambil dengan teknik simple random sampling. Data dianalis menggunakan uji Korelasi Pearson, Kruskal-Wallis dan Regresi Linear Multipel Hasil penelitian didapapatkan nilai tertinggi efikasi diri adalah perawat PK IV 80\% (174) dari nilai total, gambaran persepsi perawat terhadap jenjang karir menunjukkan hal yang positif sebesar $82 \%$ (56) dari nilai total, sedangkan gambaran efikasi diri perawat berdasarkan keyakinan diri perawat akan kemampuan melakukan asuhan keperawatan masih dibawah $80 \%$ yaitu $77,9 \%(167,52)$ dan pemahaman terhadap jenjang karir menunjukkan masih dibawah $80 \%$ yaitu $75 \%$ (36), terdapat hubungan yang bermakna antara pemahaman jenjang karir dengan efikasi diri perawat $(\mathbf{p}<0,001)$ dengan kekuatan hubungan sedang $(r=0,407)$ dan terdapat hubungan yang bermakna antara persepsi jenjang karir dengan efikasi diri perawat $(p<0,005)$ dengan kekuatan hubungan lemah $(r=0,226)$. Faktor determinan efikasi diri perawat adalah pendidikan, pemahaman, dan persepsi ( $\mathrm{r}$ square = 0,236). Penelitian ini merekomendasikan kebijakan untuk meningkatkan efikasi diri dengan melalui pendidikan formal, peningkatan pemahaman dan persepsi jenjang karir melalui pengembangan profesional berkelanjutan.
\end{abstract}

Kata kunci: Efikasi diri, jenjang karir, pemahaman

\section{Abstract}

The implementation of career ladder has an impact to improve nurses' competency, but its success particularly in providing nursing care is influenced by self-efficacy. This study aims to determine the relationship between understanding and perception of career ladder with self-efficacy in providing nursing care. This study used an explorative cross sectional study design with a sample of 182 nurses selected using simple random sampling. Data were analyzed using Pearson, Kruskal-Wallis correlation test and multivariable linear regression. The results showed that the highest value of self-efficacy was in clinical nurses IV, with $80 \%$ (174) of the total value. Nurses' positive perceptions of career ladder accounted for $82 \%$ (56) of total scores, and nurses' self-efficacy based on nurses' self-confidence and the ability to do nursing care was $77.9 \%(167.52)$ and the understanding of career ladder was $75 \%$ (36). There was a significant relationship between the understanding of career paths and nurse's selfefficacy $(p<.001)$ with moderate relationship strength $(r=.407)$. In addition, a significant relationship was also identified between the perception of career ladder and nurse self-efficacy $(p<.005)$ with weak relationship strength $(r=.226)$. The most influential determinant factor in nurse's self-efficacy was the level of education $(R$ Square $=. \mathbf{2 3 6})$. It is therefore recommended for the policies to improve nurses' self-efficacy through formal education, improvement of understanding and perception about carerr ladder through continuous profesional development.

Key words:Self-efficacy, career ladder, Understanding 


\section{PENDAHULUAN}

Perawat dituntun kompeten diberbagai keterampilan keperawatan dalam mencapai kualitas dan tujuan keperawatan pasien dalam asuhan keperawatan. Pemahaman perawat terhadap keyakinan efikasi diri klinisnya merupakan hal penting dalam peningkatan dan perbaikan praktik keperawatan. Penilaian efikasi diri perawat tentang keterampilan profesionalnya dapat menjadi dasar perencanaandalam pengembangan keterampilan perawat klinis (Welsh, 2014) Efikasi diri memberikan keyakinan kemampuan diri untuk berhasil dalam melaksanakan tugas yang diberikan (Bandura, 1978).MenurutBandura \& Wood(1989), efikasi diri adalah keyakinan dalam kemampuan diri seseorang untuk memobilisasi motivasi, sumber daya kognitif dan tindakan untuk memenuhi tuntutan tugas yang diberikan.

Peningkatan efikasi diri mampu meningkatkan kinerja staf(Golnaz, 2011). Hasil penelitian menunjukkan korelasi positif yang signifikan antara efikasi diri pekerjaan spesifik dan prestasi kerja, semakin tinggi efikasi diri pada pekerjaan tertentu, semakin tinggi pula prestasi kerjanya (Randhawa, 2016).Efikasi diri perawat diperlukan untuk keberhasilan dalam melaksanakan tugas asuhan keperawatan.

Sistem jenjang karir melalui program pengembangan profesional berkelanjutan mampu meningkatkan kompetensi keperawatan. Peningkatan efikasi diri perawat dipengaruhi oleh kompetensi keperawatan yang dimiliknya (Chao-Wen, Shieunt-Han, Ying-Ying, \& Wei-Lun, 2014).

Penelitian inibertujuan untuk mengetahui gambaran efikasi diri perawat tiap level jenjang karir (LJK), hubungan pemahaman dan persepsi jenjang karir dengan efikasi diri perawat dalam pemberian asuhan keperawatan dan faktor dominan yang paling berpengaruh terhadap efikasi diri perawat.

\section{METODE PENELITIAN}

Desain penelitian ini adalahcross sectionaleksploratifdengan ukuransampel penelitian 182 responden. Perawat yang termasuk dalam kriteria inklusi adalah perawat bekerja di instalasi rawat inap, pendidikan minimal D III keperawatan, dan bersedia untuk menjadi responden. Teknik sampling yang digunakan adalah simple random sampling. Alat pengumpul data adalah kuesioner yang terdiri dari atas 3 bagian. Bagian pertama berupa data karakteristik perawat,bagian kedua yaitu kuesioner pemahaman dan persepsi penerapan sistem jenjang karir danbagian ketiga yaitu kuesioner efikasi diri perawat dalam pemberian asuhan keperawatan.

Penelitian ini telah lolos uji etik dari tim kaji etik FIK UI 0532/UIS2.F12.D/HKP.02.04/2016.

Pengambilan data dengan cara menyebarkan kuesioner kepada perawat yang masuk dalam daftar sampel di 17 ruangan rawat inap. Data dianalisis secara diskriptif(distribusi dan persentase), analisis bivariat (korelasi pearson dan Kruskal-Wallis), analisis multivariat(regresi linear multipel.

\section{HASIL}

Hasil uji statistik gambaran karakteristik perawat:Tabel 1 menunjukkan bahwa dari 182 perawat mayoritas berjenis kelamin perempuan $(89,6 \%)$. Tingkat pendidikan perawat sebagian besar D3 keperawatan $(84,1 \%)$. Level jenjang karir(LJK) terbanyak berada pada perawat PK III $(49,5 \%)$,perawat PK II $(30,8 \%)$, perawat Pra PK terbanyak ketiga $(14,3 \%)$ Prosentasi LJK terkecil berada pada perawat PK I dan PK IV (2,7\%). Status kepegawaian perawat paling banyak adalah Aparatur Sipil Negara (ASN) (81,9\%), karyawan tidak tetap (KTT) $(16,5 \%)$ dan terdapat perawat dari unsur TNI $(1,6 \%)$.Nilai median usia perawat 36 tahun dengan usia termuda 20 tahun dan usia tertua 58 tahun. Nilai median masa kerja perawat 11,50 tahun dengan masa kerja tersingkat 1 tahun dan masa kerja terlama 38 tahun. 
Tabel 1. Karakteristik Perawat Berdasarkan Jenis kelamin, Pendidikan Terakhir, Level Jenjang Karir, dan Status Kepegawaian Desember $2016(n=182)$

\begin{tabular}{clcc}
\hline No & \multicolumn{1}{c}{ Variabel } & Frek & $(\%)$ \\
\hline 1 & Jenis Kelamin & & \\
& Laki-laki & 19 & 10,4 \\
& Perempuan & 163 & 89,6 \\
2 & Pendidikan & & \\
& D3 Keperawatan & 153 & 84,1 \\
& Ners & 29 & 15,9 \\
& & & \\
3 & LJK & & \\
& Pra PK & 26 & 14,3 \\
& PK I & 5 & 2,7 \\
& PK II & 56 & 30,8 \\
& PK III & 90 & 49,5 \\
& PK IV & 5 & 2,7 \\
4 & Status pegawai & & 1,6 \\
& TNI & 3 & 81,9 \\
& ASN & 149 & 16,5 \\
\hline
\end{tabular}

Tabel 2. Karakteristik Perawat Berdasarkan Usia dan Masa Kerja Instalasi Rawat Inap Desember $2016(n=182)$

\begin{tabular}{lccc}
\hline \multicolumn{1}{c}{ Variabel } & Median & $\begin{array}{c}\text { Minimum } \\
\text { Maksimum }\end{array}$ & $95 \%$ CI \\
\hline $\begin{array}{l}\text { Usia (dalam tahun) } \\
\begin{array}{l}\text { Masa kerja (dalam } \\
\text { tahun) }\end{array}\end{array}$ & 36,00 & $20-58$ & $35,72-38,38$ \\
\hline
\end{tabular}

Tabel 3. Hubungan level Jenjang Karir, Pemahaman dan Persepsi Penerapan Sistem Jenjang Karir dengan Efikasi Diri Perawat dalam Pemberian Asuhan di Instalasi Rawat inap RSX

\begin{tabular}{|c|c|c|c|c|c|}
\hline Variabel & $\begin{array}{c}\text { Sub } \\
\text { Variabel }\end{array}$ & $\mathrm{N}$ & $\begin{array}{c}\text { Indek } \\
\text { Brinkman }\end{array}$ & $\mathrm{r}$ & $p$ \\
\hline \multirow{5}{*}{$\begin{array}{l}\text { Level } \\
\text { Jenjang } \\
\text { Karir }\end{array}$} & Pra PK & 26 & $\begin{array}{c}171,5 \\
(129-208)\end{array}$ & - & 0,146 \\
\hline & PK I & 5 & $\begin{array}{c}168 \\
(133-179)\end{array}$ & & \\
\hline & PK II & 56 & $\begin{array}{c}171 \\
(122-215)\end{array}$ & & \\
\hline & PK III & 90 & $\begin{array}{c}165 \\
(127-213)\end{array}$ & & \\
\hline & PK IV & 5 & $\begin{array}{c}174 \\
(172-215)\end{array}$ & & \\
\hline Pemahaman & - & & - & 0,407 & 0,000 \\
\hline Persepsi & - & & - & 0,226 & 0,002 \\
\hline
\end{tabular}

Tabel 2 menunjukkan nilai tertinggi efikasi diri perawat pada level PK IV dengan nilai median efikasi 174 (80,9\%), nilai terendah 172 dan nilai tertinggi 215 . Tidak terdapat hubungan signifikan antara level jenjang karir dengan efikasi diri perawat dalam pemberian asuhan keperawatan. Hasil penelitian menunjukkan terdapat hubungan yangbermakna antara pemahaman jenjang karir dengan efikasi diri perawat $(\mathrm{p}<0,001)$ dengan kekuatan hubungan sedang $(\mathrm{r}=0,407)$ dan terdapat hubungan yang bermakna antara persepsi jenjang karir dengan efikasi diriperawat $(\mathrm{p}<0,005)$ dengan kekuatan hubungan lemah $(\mathrm{r}=0,226)$.

Tabel 4. Pemodelan Akhir Variabel yang Berhubungan dengan Efikasi Diri Perawat di Instalasi Rawat RSX

\begin{tabular}{ccccccc}
\hline & & & & & $\mathrm{R}$ \\
No & Model & $\mathrm{B}$ & $\begin{array}{c}\text { Std. } \\
\text { Error }\end{array}$ & $\mathrm{R}$ & $\begin{array}{c}\mathrm{Sq} \\
\mathrm{uar}\end{array}$ & $p$ \\
& & & & $\mathrm{e}$ & \\
\hline & (Constant) & 83,192 & 12,193 & 0,486 & 0,2 & 0,000 \\
1 & $\begin{array}{l}\text { Pema- } \\
\text { haman }\end{array}$ & 1,387 & 0,255 & & & 0,000 \\
2 & $\begin{array}{l}\text { Persepsi } \\
\text { Tingkat } \\
\text { pendidikan }\end{array}$ & 0,411 & 0,155 & & & 0,009 \\
& & 10,497 & 3,771 & & & 0,007 \\
\hline
\end{tabular}

Tabel 3 menunjukkan pemodelan akhir multivariat meliputi tingkat pendidikan, pemahaman dan persepsi penerapan sistem jenjang karir. Jenis persamaan pemodelan akhir adalah sebagai berikut:

$\mathrm{Z}$ efikasi diri $=83,192+10,497 x$ tingkat pendidikan+1,387xpemahaman penerapan sistem jenjang karir $+0.411 \mathrm{x}$ persepsi penerapan sistem jenjang karir.

Tingkat efikasi diri perawat di Instalasi rawat inap RSX sebesar $23,6 \%$ bisa dijelaskan oleh pendidikan, pemahaman, dan persepsi, sedangkan selebihnya $76,4 \%$ bisa dijelaskan oleh faktor lain.yang tidak dilibatkan dalam penelitian ini.

\section{PEMBAHASAN \\ HubunganLevel Jenjang Karir, Pemahaman, dan Persepsi dengan Efikasi Diri}

Studi literatur menunjukkan bahwa perawat pemula dengan efikasi diri kuat, memiliki komitmen kuat untuk menggunakan keterampilan klinisnya dan memiliki kesempatan yang lebih baik untuk memenuhi tujuan klinisnya (Franklin, Gubrud-Howe, Sideras, \& Lee, 2015). Peningkatan efikasi diri perawat dipengaruhi oleh kompetensi keperawatan yang dimiliki. Perawat dengan kemampuan kompetensi klinis tinggi akan tinggi pula efikasi dirinya. Kompetensi 
memiliki hubungan posistif dengan efikasi diri (Chao-Wen et al., 2014).

Hasil penelitian ini menunjukkan bahwa tidak ada hubungan signifikan antara level jenjang karir dengan efikasi diri perawat dalam pemberian asuhan keperawatan antara perawat Pra PK, PK I, PK II, PK III dan PK IV. Hasil penelitian ini sejalan dengan penelitian Afriani (2015) yang menyatakan tidak ada hubungan antara penjenjangan level jenjang karir hasil mapping dengan ekspektasi terhadap penerapan jenjang karir. Penelitian Mashudi (2013) menyatakan sebaliknya,adanya hubungan yang sangat bermakna antara level jenjang karir dengan kinerja perawat dan juga antara level jenjang karir dengan kepuasan kerja.

Mempertahankan dan meningkatan kompetensi perawat dalam sistem jenjang karir dilaksanakan melalui program pengembangan profesional berkelanjutan. Program ini dilaksanakan untuk mengatasi gap kompetensi yang belum dikuasai perawat. Keberhasilan pengembangan profesional berkelanjutan mampu meningkatkan efikasi diri perawat (Mannix, Wilkes, \& Luck, 2009). Ziegler (2006)menyatakan bahwa latihan adalah sumber paling penting dari efikasi karena mengandalkan pengalaman pribadi yang sebenarnya.

Peneliti berpendapat tidak adanya hubungan bermakna antara level jenjang karir dengan efikasi diri perawat dalam pemberian asuhan keperawatan dapat disebabkan oleh: (1) Belum maksimalnya upaya penjaminan pengembangan profesional berkelanjutan. Program ini merupakan upaya pendekatan pembelajaran secara mandiri, berkelanjutan, sistematis, berfokus pada hasil untuk mempertahankan dan meningkatkan kompetensi yang menjadi tanggung jawab pribadi didorong oleh kebutuhan belajar (Dopp, Moulton, Rouse, \& Trewet, 2010). (2) Belum optimalnya kompetensi yang dikuasai perawat sesuai dengan level jenjang karirnya berdasarkan daftar rincian kewenangan klinis. (3) Belum maksimalnya pencapaian log book yaitu proses pencapaian aktivitas yang dilaksanakan oleh individu perawat dalam menjalankan peran dan tugas dalam memberikan asuhan keperawatan
Hasil penelitian menunjukkan terdapat hubungan signifikan antara persepsi jenjang karir dengan efikasi diri perawat di Instalasi Rawat Inap RS X dengan kekuatan hubungan lemah $(r=0,226)$. Moorhead dan Griffin (2010) menyatakan bahwa persepsi adalah serangkaian proses yang disadari oleh individu dalam menafsirkan lingkungan. Robbins dan Coulter (2010) menyatakan bahwa persepsi adalah proses mengartikan lingkungan sekitar dengan menyusun dan menginterpretasikan impresi sensori. Faktor lingkungan dapat mempengaruhi keyakinan efikasi diri perawat secara positif dan negatif. Lingkungan kerja yang mendukung dapat meningkatkan efikasi diri dan kinerja profesional (Raica, 2009).

Penerapan sistem jenjang karir memberikan peluang meningkatkan efikasi diri perawat karena memberikan kesempatan untuk belajar keterampilan baru (Vandervort, 2008). Lingkungan pembelajaran klinik merupakan sumber utama peningkatan efikasi diri perawat (Gloudemans, Schalk, Reynaert, \& Braeken, 2013). Hasil penelitian Desmaliza (2005) menyatakan bahwa terdapat hubungan yang signifikan antara iklim sekolah dengan efikasi diri santri terhadap prestasi belajar. Peneliti berpendapat bahwa adanya hubungan persepsi penerapan sistem jenjang karir dengan efikasi diri perawat dikarenakan adanya persepsi yang positif perawat terhadap tujuan dan manfaat penerapan sistem jenjang karir di RS X. Persepsi positif ini dibentuk dari pengalaman masa lalu dan proses belajar yang dilalui sebelumnya.

Hasil penelitian menunjukkan terdapat hubungan signifikan antara pemahaman penerapan sistem jenjang karir dengan efikasi diri perawat. Hal ini sesuai dengan pendapat Welsh (2014) menyatakan bahwa pemahaman dan pengalaman yang baik dapat meningkatkan keyakinan efikasi diri perawat dan sebaliknya kurangnya pengetahuan dan pengalaman dapat mengakibatkan rendahnya keyakinan efikasi diri perawat pada kompetensi klinik. Penulis berpendapat bahwa terdapatnya hubungan pemahaman penerapan sistem jenjang karir dengan efikasi diri perawat menunjukkan bahwa adanya 
pemahaman perawat benar tentang jenjang karir.

Pengetahuan perawat menjadi hambatan untuk mengikuti sistem jenjang karir dan peningkatan efikasi dirinya. Carryer, Russell, dan Budge (2007) menekankan perlunya peningkatan pengetahuan dan memberikan pendidikan tentang sistem jenjang karir, sehingga perawat cenderung mengembangkan perilaku positif bila perawat lebih memahami tentang sistem ini. Welsh (2014) menyatakan bahwa pencapaian keberhasilan peningkatan kepercayaan diri perawat akan efikasi diri dalam melaksanakan asuhan keperawatan diperlukan support system yang dapat membantu perawat memahami sistem jenjang karir dan kompeten dalam melaksanakan tugas melalui pendidikan formal, pendidikan dan pelatihan keterampilan khusus, bimbingan dari perawat ahli yang berpengalaman, meminta kesempatan berlatih keterampilan dengan bimbingan, terlibat aktif dalam perawatan pasien yang penuh tantangan, mengakui keberhasilan diri dan melanjutkan pengembangan keterampilan yang diperlukan (Welsh, 2014).

\section{Faktor Dominan yang paling berpengaruh} Terhadap Efikasi Diri Perawat

Hasil Penelitian menunjukkan faktor dominan yang paling berpengaruh pada efikasi diri perawat adalah tingkat pendidikan, selain itu pemahaman dan persepsi penerapan sistem jenjang karir juga berpengaruh terhadap efikasi diri perawat dalam pemberian asuhan keperawatan.

Notoatmodjo (2003) menyatakan bahwa tingkat pendidikan merupakan indikator bahwa seseorang telah menyelesaikan jenjang pendidikan formal tertentu. Seseorang dengan pendidikan yang baik, lebih matang terhadap proses perubahan pada dirinya sehingga lebih mudah menerima pengaruh dari luar yang positif, objektif dan terbuka terhadap berbagai informasi. Temple (2003) menyatakan bahwa keyakinan akan kemampuan diri (efikasi diri) dalam pemberian asuhan keperawatan dihasilkan dari interaksi pengetahuan, sikap dan tindakan terhadap pelaksanaan asuhan keperawatan. Peterson \& Bedrow (2004) menyatakan seseorang akan memutuskan untuk berperilaku berdasarkan pemikiran reflektif,penggunaan pengetahuan secara umum dan kemampuan untuk melakukan suatu tindakan tertentu.

Bandura (1994) menyatakan bahwa proses pemahaman mempengaruhi pola fikir yang dapat mendorong dan menghambat perilaku seseorang. Sebagaian orang akan berfikir dahulu sebelum bertindak. Pemahaman merupakan hal penting dalam membentuk efikasi diri. Keberhasilan suatu tindakan akan memberikan pengalaman pribadi yang akan berpengaruh penting pada penguatan efikasi diri perawat. Menurut (Ziegler, 2006)menyataka bahwa pengalaman keberhasilan mengubah keyakinan perawat akan kekuatan efikasi dirinya.

$$
\text { Robbins \& Coulter (2010) }
$$

menyatakan bahwa persepsi merupakan proses penilaian lingkungan sekitar dengan menginterpretasikan impresi sensoris. Penilaian persepsi secara konsisten menunjukkan bahwa setiap orang bisa melihat yang sama tetapi beda mempersepsikannya. Seseorang berperilaku berdasarkan persepsinya.

\section{SIMPULAN}

Hasil penelitian menunjukkan terdapat hubungan yangbermakna antara pemahaman dan persepsi jenjang karir dengan efikasi diri perawat dalam pemberian asuhan keperawatan

Penelitian ini menemukan variabel yang paling berpengaruh pada efikasi diri perawat dalam pemberian asuhan keperawatan adalah tingkat pendidikan. Semakin tinggi tingkat pendidikan perawat akan meningkatkan efikasi diri perawat dalam pemberian asuhan keperawatan sebanyak 10, 5 kali setelah dikontrol oleh pemahaman dan persepsi penerapan sistem jenjang karir. Semakin tinggi tingkat pemahaman penerapan sistem jenjang karir akan meningkatkan efikasi diri perawat dalam pemberian asuhan keperawatan sebanyak 1,4 kali setelah dikontrol oleh tingkat pendidikan dan persepsi penerapan sistem jenjang karir. Semakin baik persepsi penerapan sistem jenjang karir akan meningkatkan efikasi diri perawat dalam 
pemberian asuhan keperawatan sebanyak 0,4 kali setelah dikontrol oleh tingkat pendidikan dan pemahan penerapan sistem jenjang karir.

\section{SARAN}

Rumah sakit diharapkan dapat menindaklanjuti hasil penelitian ini dengan membuat kebijakan mengenai strategi untuk meningkatkan efikasi diri perawat klinis melalui pendidikan formal.

\section{UCAPAN TERIMA KASIH}

Ucapan rasa terima kasih penulis sampaikan kepada Ibu Dr. RR. Tutik Sri Hariyati, SKp, MARS dan Ibu Dr. Tuti Nuraini, SKp., M. Biomed yang telah memberikan bimbingan dan arahan dalam pembuatan manuskrip ini dan juga kepada Joko Gunawan, Ph.D sebagai translater serta kepada reviewer dan TIM Pengelola JKP yang telah banyak membantu sehingga manuskrip ini dapat diselesaikan dengan baik.

\section{DAFTAR PUSTAKA}

Bandura, A. (1978). Self-efficacy: Toward a unifying theory of behavioral change. Advances in Behaviour Research and Therapy, 1(4), 139-161. http://doi.org/10.1016/01466402(78)90002-4

Bandura, A., \& Wood, R. (1989). Effect of perceived controllability and performance standards on self-regulation of complex decision making. Journal of Personality and Social Psychology, 56(5), 805-814. http://doi.org/10.1037/00223514.56.5.805

Chao-Wen, T., Shieunt-Han, T., Ying-Ying, C., \& Wei-Lun, L. (2014). A study of nursing competency, career self-efficacy and professional commitment among nurses in Taiwan. Contemporary Nurse, 49(December), 96-102. Retrieved from http://search.proquest.com/docview/1644 146177 ? accountid=17242

Franklin, A. E., Gubrud-Howe, P., Sideras, S.,
\& Lee, C. S. (2015). Effectiveness of simulation preparation on novice nurses' competence and self-efficacy in a multiple-patient simulation. Nursing Education Perspectives, 36(5), 324-325. http://doi.org/10.5480/14-1546

Gloudemans, H., Schalk, R., Reynaert, W., \& Braeken, J. (2013). The development and validation of a five-factor model of Sources of Self-Efficacy in clinical nursing education, 3(3), 80-88. http://doi.org/10.5430/jnep.v3n3p80

Golnaz, S. (2011). Boosting Performance Through Self-Efficacy. $T+D, 65(6)$, 30-31. Retrieved from http://search.proquest.com/docview/1633 950477? accountid $=17242$

Mannix, J., Wilkes, L., \& Luck, L. (2009). Key stakeholders in clinical learning and teaching in bachelor of nursing programs : A discussion paper, 32(1), 59-68.

Raica, D. A. (2009). Effect of action-oriented communication training on nurses' communication self-efficacy. MEDSURG Nursing, 18(6), 343-360. Retrieved from http://ezp.waldenulibrary.org/login?url= http://search.ebscohost.com/login.aspx?d irect $=$ true $\& d b=a 9 h \& A N=46837528 \&$ sit $\mathrm{e}=\mathrm{eds}-$

live \&scope $=$ sitelnhttp://content.ebscohos t.com/ContentServer.asp?T $=\mathrm{P} \& \mathrm{P}=\mathrm{AN} \&$ $\mathrm{K}=46837528 \& \mathrm{~S}=\mathrm{R} \& \mathrm{D}=\mathrm{a} 9 \mathrm{~h} \&$ EbscoCont ent=dGJyMNLr40Sep7Y4v+v1OLCmr0 2ep

Randhawa, G. (2016). Self-efficacy and work performance : An empirical study, 39(3), 336-346. Retrieved from http://www.jstor.org/stable/27767910

Vandervort, A. (2008). Clinical ladder benefits staff, manager. OR Manager, 24(7), 13-14. Retrieved from http://search.proquest.com/docview/2130 89282 ? accountid $=17242$ 
Welsh, D. (2014). Self-efficacy measurement and enhancement strategies for medicalsurgical clinical nurses. Medsurg Nursing, 23(6), 371-378. Retrieved from http://search.proquest.com/docview/1640 742236 ? accountid $=17242$

Ziegler, S. M. (2006). Theory-Directed Nursing Practice (2nd ed). International Journal, 20(2), 173-174. 